\title{
Sistem Pemandu Pendaratan pada Balon Udara Berbasis Pengolahan Citra dan Kendali PID
}

\author{
Agung Andri Kurniawan, Muhammad Rivai, dan Fajar Budiman \\ Jurusan Teknik Elektro, Fakultas Teknologi Industri, Institut Teknologi Sepuluh Nopember (ITS) \\ Jl. Arief Rahman Hakim, Surabaya 60111 \\ e-mail:muhammad_rivai@ee.its.ac.id, fajarbudiman@ee.its.ac.id, agung.andri12@mhs.ee.its.ac.id
}

\begin{abstract}
Abstrak-Riset dan pengembangan studi Unmanned Aerial Vehicle (UAV) atau pesawat tanpa awak tengah berkembang pesat. Banyak perusahaan besar memfokuskan dalam kegiatan ini, mulai dari aplikasi untuk pengantaran barang, teknologi bertani, hingga untuk penanganan bencana alam. UAV menggunakan sistem Navigasi Global Positioning System (GPS) untuk memandu menuju lokasi tujuan. Navigasi dengan GPS mempunyai kelemahan yaitu rawan terhadap error hingga mencapai puluhan meter. Sehingga dapat menyebabkan masalah pada saat mendarat di lokasi tujuan. Maka dari itu, dirancanglah sistem pemandu pendaratan pada UAV dalam hal ini balon udara untuk membantu navigasi GPS dalam meningkatkan keakuratan pendaratan. Dengan bantuan pengolahan citra, sistem akan membantu mengenali pola dari landasan dengan metode $\mathrm{Hu}$ Moments contour matching yang tidak berubah secara skala, rotasi, dan translasi. Dari hasil percobaan sistem dengan metode $\mathrm{Hu}$ Moments contour matching, didapatkan tingkat keakurasian sebesar $94 \%$ pada perubahan skala secara ketinggian, $94 \%$ pada perubahan rotasi.
\end{abstract}

Kata Kunci-UAV, Contour Matching, Pengolahan Citra

\section{PENDAHULUAN}

$\mathrm{P}$ ENGGUnAan teknologi Unmanned Aerial Vehicle (UAV) atau Pesawat Tanpa Awak dewasa ini banyak berkembang pada negara maju. UAV adalah mesin terbang yang dapat dikendalikan secara jarak jauh oleh pilot maupun secara autopilot. Contoh dari UAV sendiri dapat berupa quadcopter, helicopter, dan balon udara. UAV sendiri banyak digunakan pada bidang militer dan sipil seperti pengintaian musuh, pengawasan suatu wilayah yang sulit dijangkau, monitoring kualitas udara suatu daerah, maupun eksplorasi gas dan minyak bumi[1]. Banyak dari aplikasi UAV diatas memerlukan fitur autopilot untuk melakukan monitoring dan pengawasan secara berkelanjutan.

Fitur autopilot pada UAV sangat berguna untuk mengatur rute pengambilan data, keberangkatan, dan landing secara otomatis. Autopilot pada UAV mengandalkan Global Positioning System (GPS) sebagai acuan utama untuk penentuan rute yang akan dilalui [2]. Kekurangan dari sistem ini adalah keakuratan dan ketelitian pada GPS yang dapat berorde meter. Sehingga pada saat landing UAV beresiko mendarat pada titik yang berbahaya dan dapat menimbulkan kerusakan pada UAV.

Oleh karena itu dalam tugas akhir ini akan dirancang sebuah sistem yang dapat membantu meningkatkan ketelitian dan keakuratan GPS untuk mengenali titik pendaratan yang diinginkan. Salah satunya adalah dengan menggunakan bantuan kamera melalui pengolahan citra untuk mengoptimalkan pendaratan pada UAV.

\section{DASAR TEORI}

\section{A. Balon Udara Blimps}

Balon Udara Blimps adalah tipe kendaraan udara yang termasuk dalam Ligther-Than-Air (LTA) craft. Disebut Lighter-Than-Air dikarenakan blimps menggunakan komponen helium yang mempunyai massa jenis lebih ringan dari udara untuk membantu mengangkat pesawat.

Balon Udara blimps menggunakan helium sebagai gaya angkat untuk terbang yang dikandung dalam envelope. Kontrol utama dari balon blimps pada dasarnya menggunakan motor yang berfungsi sebagai pendorong ke depan, elevate (mendorong ke atas atau ke bawah), dan rudder (untuk membelokkan kemudi) [4]. Penggunaan Balon Udara dalam UAV untuk aplikasi tertentu mempunyai beberapa kelebihan dimana tingkat keamanan, kemudahan penggunaan, dan kemampuan dalam terbang lebih baik daripada helikopter maupun quadcopter.

Balon Udara mempunyai tiga bagian utama yaitu: envelope, gondola, dan engine. Envelope bentuknya berupa kantong berupa balon tempat untuk helium. Envelope ini biasanya dilapisi dengan bahan anti api. Gondola biasanya berisi penumpang atau barang yang dinaikkan dalam balon udara. Engine berupa motor untuk menggerakkan balon udara.

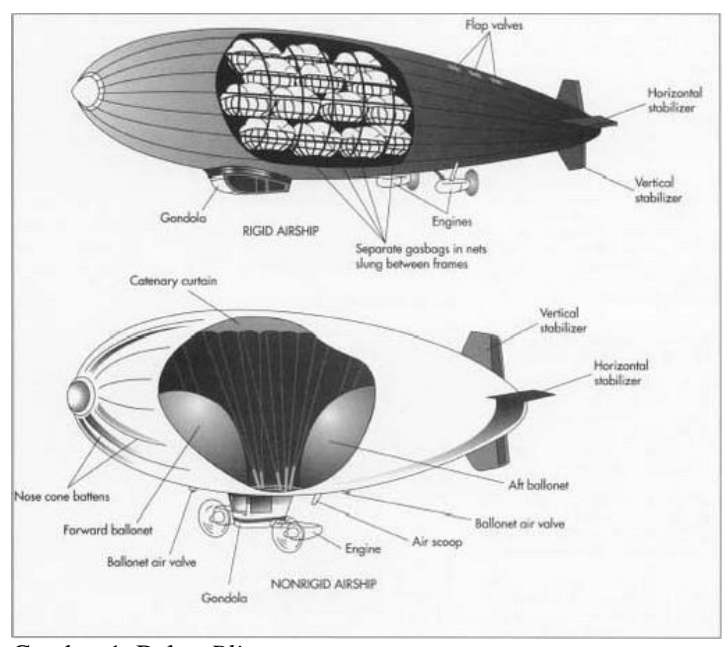

Gambar 1. Balon Blimps 


\section{B. Sensor Ultrasonic}

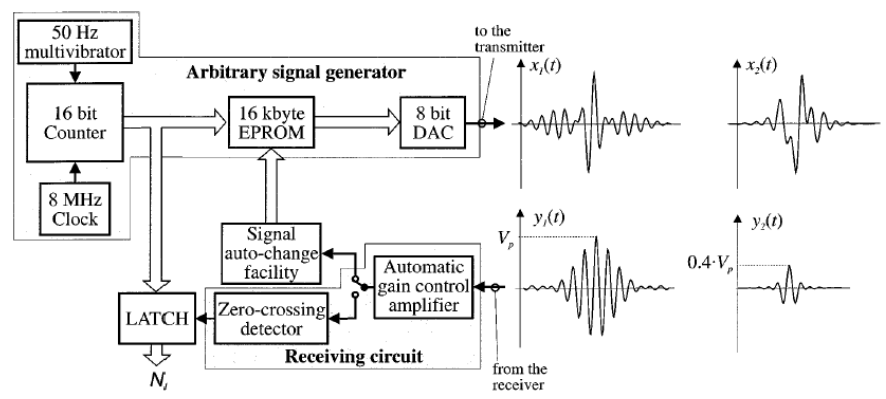

Gambar 2. Contoh Sinyal Trigger dan Echo pada Ultrasonic

Sensor ultrasonic adalah sensor yang bekerja dengan prinsip pantulan (echo) dengan menggunakan dua buah transduser piezoelectric, dengan satu transduser untuk memancarkan gelombang dan yang lainnya menerima gelombang hasil pantulan tersebut [3]. Jarak dari sensor dari obyek yang akan dideteksi dapat dihitung dengan persamaan sebagai berikut:

$$
S=\frac{\operatorname{TIn} x V}{2}
$$

Dengan :

S : jarak obyek dengan benda

Tin : adalah selisih waktu pemancaran dan penerimaan pantulan gelombang

$\mathrm{V}$ : Kecepatan suara pada udara $(340 \mathrm{~m} / \mathrm{s})$

Transduser ini biasanya mempunyai frekuensi resonansi 40 $\mathrm{KHz}$ yang digunakan untuk menciptakan gelombang ultrasonic. Salah satu keuntungan dari pemakaian prinsip kerja sensor ultrasonic dengan metode time of flight atau waktu tempuh, yaitu waktu yang diperlukan dari transmitter menuju receiver kita dapat memperkirakan berapa jarak suatu benda terhadap sensor ultrasonic tersebut.

\section{Hu Invariant Moments}

$\mathrm{Hu}$ Invariant Moments pertama kali dipublikasikan oleh $\mathrm{Hu}$ pada tahun 1961 dan Hu Invariant Moments di reformula oleh Li. Nilai-nilai yang dihasilkan dari $\mathrm{Hu}$ Invariant Moments ini terdiri dari tujuh nilai yang menidentifikasikan ciri dari sebuah objek citra digital. Nilai-nilai tersebut bersifat independen terhadap translasi, rotasi dan penskalaan .Moments yang mentransformasikan fungsi citra $\mathrm{f}(\mathrm{i}, \mathrm{j})$ pada sistem diskrit dinyatakan dengan persamaan:

$$
\mu_{p q}=\sum_{X=0}^{H-1} \sum_{y=0}^{w-1}(x-\bar{x})^{p}(y-\bar{y})^{q} f(x, y)
$$

dimana:

$$
\bar{x}=\frac{m 10}{m 00} \operatorname{dan} \bar{y}=\frac{m 01}{m 00}
$$

kemudian normalized central moments, didefinisikan sebagai berikut:

$$
\eta_{p q}=\frac{\mu_{p q}}{\mu_{p q^{y}}}, y=\frac{p+q}{2}+1
$$

Sehingga ketujuh nilai invariant moments dapat diturunkan dari moment kedua dan ketiga sebagai berikut.

$$
\begin{aligned}
\phi 1= & \eta_{20}+\eta_{02} \\
\phi 2= & \left(\eta_{20}-\eta_{02}\right)^{2}+4 \eta_{11}{ }^{2} \\
\phi 3= & \left(\eta_{30}-3 \eta_{12}\right)^{2}+\left(3 \eta_{21}+\eta_{03}\right)^{2} \\
\phi 4= & \left(\eta_{30}+\eta_{12}\right)^{2}+\left(\eta_{21}+\eta_{03}\right)^{2} \\
\phi 5= & \left(\eta_{30}-3 \eta_{12}\right)\left(\eta_{30}+\eta_{12}\right)\left[\left(\eta_{30}+\eta_{12}\right)^{2}-\left(3 \eta_{21}+\eta_{03}\right)^{2}\right]+ \\
& \quad\left(3 \eta_{21}-\eta_{03}\right)\left(\eta_{21}+\eta_{03}\right)\left[\left(3 \eta_{30}+\eta_{12}\right)^{2}-\left(\eta_{21}+\eta_{03}\right)^{2}\right] \\
\phi 6= & \left(\eta_{20}-3 \eta_{02}\right)\left[\left(\eta_{30}+\eta_{12}\right)^{2}-\left(\eta_{21}+\eta_{03}\right)^{2}\right]+ \\
& 4 \eta_{11}\left(\eta_{30}-\eta_{12}\right)\left(\eta_{21}+\eta_{03}\right) \\
\phi 7= & \left(3 \eta_{21}-\eta_{03}\right)\left(\eta_{30}+\eta_{12}\right)\left[\left(\eta_{30}+\eta_{12}\right)^{2}-3\left(\eta_{21}+\eta_{03}\right)^{2}\right] \\
& +\left(\eta_{30}+\eta_{12}\right)\left(\eta_{21}+\eta_{03}\right)\left[3\left(\eta_{30}+\eta_{12}\right)^{2}-\left(\eta_{21}+\eta_{03}\right)^{2}\right]
\end{aligned}
$$

\section{Contour matching}

Metode contour matching dengan $\mathrm{Hu}$ Moments mampu mendeteksi kontur yang berbeda secara skala, rotasi, dan translasi dengan cara menjumlahkan semua nilai hasil pengurangan dari moments target dan moments yang akan dideteksi [5]. Dengan mengurangkan ketujuh nilai $\mathrm{Hu}$ Moments pada dua gambar yang identik nilai dari moments tersebut akan bernilai mendekati nol.

$$
I 1(A, B)=\sum_{i=1,2, . ., 7}\left|\frac{1}{m_{i}^{a}}-\frac{1}{m_{i}^{b}}\right|
$$

\section{E. Kendali Proportional Integral Derivatif}

Penggunaan kendali PID pada industri penerbangan sudah banyak digunakan dengan berbagai macam jenis mulai dari algoritma yang simpel, mempunyai presisi tinggi, dengan struktur yang kuat, dan mempunyai tingkat keandalan yang baik [6]. Kendali PID merupakan kontroler untuk menentukan presisi suatu sistem instrumentasi dengan karakteristik adanya umpan balik pada sistem tesebut. Komponen kontrol PID ini terdiri dari tiga jenis yaitu Proportional, Integratif dan Derivatif. Ketiganya dapat dipakai bersamaan maupun sendirisendiri tergantung dari respon yang kita inginkan terhadap suatu plant. PID Blok Diagram dapat dilihat pada gambar dibawah:

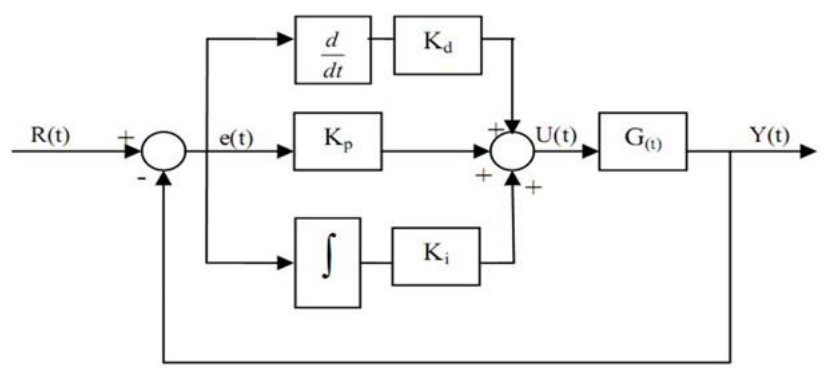

Gambar 3. Diagram Blok PID

Persamaan pengontrol PID datas dapat juga dituliskan sebagai berikut: 
$\mathrm{y}(\mathrm{t})=\left(K_{\mathrm{P}} e(t)+K_{i} \int_{0}^{t} e(t) d t+K_{d} \frac{d e(t)}{d t}\right)$

dengan :

$$
K_{i}=\frac{1}{T_{i}} \times \mathrm{K}_{\mathrm{p}} \text { dan } K_{d}=\mathrm{K}_{\mathrm{p}} \times \mathrm{T}_{\mathrm{d}}
$$

Keterangan:

$y(t)$ : output dari pengontrol PID atau Manipulated Variable

$K p$ : konstanta Proporsional

$T i$ : konstanta Integral

$T d$ : konstanta Detivatif

$e(t)$ : error (selisih antara set point dengan level aktual)

Komponen kontrol PID ini terdiri dari tiga jenis yaitu Proportional, Integratif dan Derivatif. Ketiganya dapat dipakai bersamaan maupun sendiri-sendiri tergantung dari respon yang kita inginkan terhadap suatu plant.

\section{F. Ziegler-nichols open loop tuning method}

Penentuan parameter kontroler PID adalah hal yang sangat penting untuk menentukan bagaimana performa dari kontrol plant tersebut pada suatu sistem, Hal ini disebut juga dengan tuning kontroler. Terkadang pemodelan matematis suatu plant susah untuk dilakukan. Jika hal ini terjadi maka perancangan kontroler PID secara analitis tidak mungkin dilakukan sehingga perancangan kontroler PID harus dilakukan secara eksperimental. Pada metode ziegler-nichols open loop aturan perpotongan garis kurva S pada grafik output plant yang diberi input unit step sangatlah penting, karena mempengaruhi nilai $\mathrm{T}$ dan $\mathrm{L}$. Setelah nilai $\mathrm{L}$ dan $\mathrm{T}$ diketahui, dengan menggunakan formula yang telah dirumuskan oleh zieglernichols kita dapat menentukan perkiraan nilai $\mathrm{Kp}, \mathrm{Ki}$, dan $\mathrm{Kd}$ yang optimal untuk plant yang akan kita kontrol.

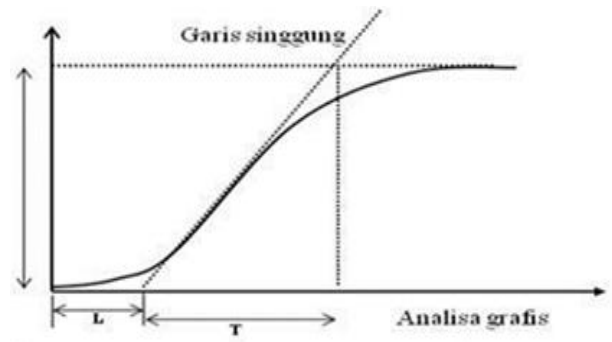

Gambar 4. Analisa grafis pada open loop

Tabel 1.

Formula ziegler-nichols pada metode open loop

\begin{tabular}{cccc}
\hline \hline Tipe Pengendali & $\mathrm{Kp}$ & $\mathrm{Ki}$ & $\mathrm{Kd}$ \\
\hline $\mathrm{P}$ & $\frac{T}{L}$ & $\infty$ & 0 \\
PI & $\frac{0.9 T}{L}$ & $0.27 \frac{T}{L^{2}}$ & 0 \\
PID & $\frac{1.2 T}{L}$ & $0.6 \frac{T}{L^{2}}$ & $0.6 \mathrm{~T}$ \\
\hline \hline
\end{tabular}

\section{PERANCANGAN SISTEM}

\section{A. Diagram Blok Sistem}

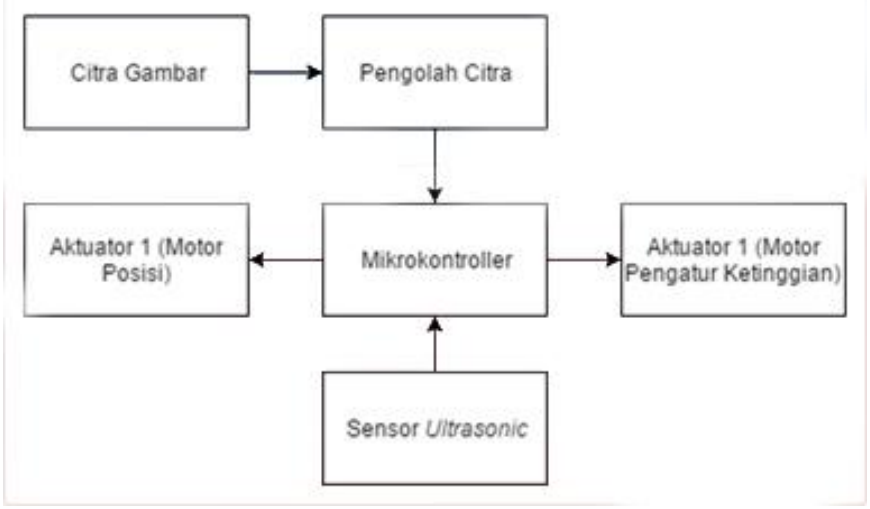

Gambar 5. Diagram blok sistem pada balon udara

Perangkat keras untuk pemrosesan data pada sistem ini adalah raspberry pi dan arduino, citra gambar yang ditangkap oleh kamera akan diproses untuk mengenali landasan pada raspberry pi dan output dari pemrosesan citra gambar berupa sudut untuk menuju landasan. Setelah besar sudut ditemukan akan ditentukan pergerakan dan kecepatan motor yang sesuai untuk menentukan sudut belok menuju titik pendaratan.

Mikrokontroller yang digunakan untuk mengolah kecepatan, arah, dan mengukur ketinggian balon udara adalah arduino. Keluaran sinyal Pulse Width Modulation (PWM) pada arduino digunakan untuk mengatur kecepatan motor dan sensor ultrasonic berfungsi untuk mengetahui ketinggian balon udara.

\section{B. Pengenalan Pola Landasan}

Dalam pengenalan pola landasan, proses pertama yang dilakukan adalah preprocessing citra yang berfungsi untuk mendapatkan hasil yang maksimal saat dilakukannya pengolahan citra. Preprocessing mengolah data citra yang mentah menjadi data citra yang siap untuk diproses selanjutnya dengan melewati proses pengubahan ruang warna dari RGB ke HSV hingga proses morfologi citra. Kedua proses tersebut sangat penting untuk menfilter warna dan mengurangi noise pada citra yang akan diproses.

Setelah data citra yang didapatkan melewati proses preprocessing, selanjutnya data yang telah didapatkan akan diproses untuk dapat mengenali landasan. Metode pengenalan landasan yang dilakukan adalah dengan menemukan kontur dari target dan kontur template yang digunakan untuk mengenali target. Setelah kontur luar dari tiap data citra didapatkan, ketujuh nilai $\mathrm{Hu}$ Moments dari kedua target tersebut akan dihitung, ketujuh nilai moments tersebut akan terus dihitung dan dibandingkan. Untuk metode perbandingan yang dilakukan dengan $\mathrm{Hu}$ Moments ini adalah dengan terus mengurangi ketujuh nilai $\mathrm{Hu} \mathrm{Moments} \mathrm{dari} \mathrm{kedua} \mathrm{gambar} \mathrm{ini}$ secara terus menerus.

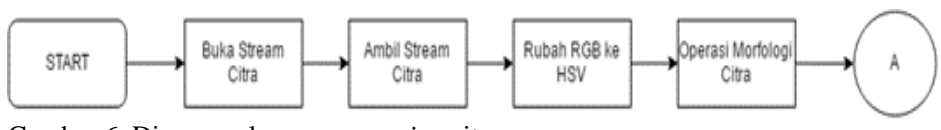

Gambar 6. Diagram alur preprocessing citra 


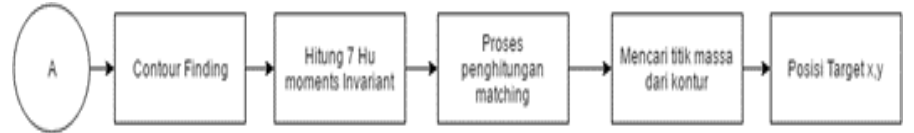

Gambar 7. Diagram alur pengenalan landasan

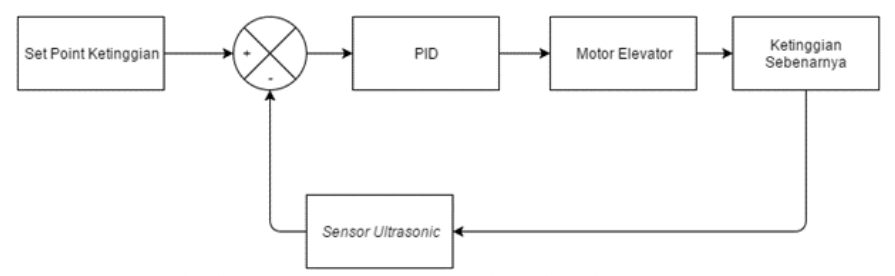

Gambar 8. Blok diagram kontrol PID untuk ketinggian

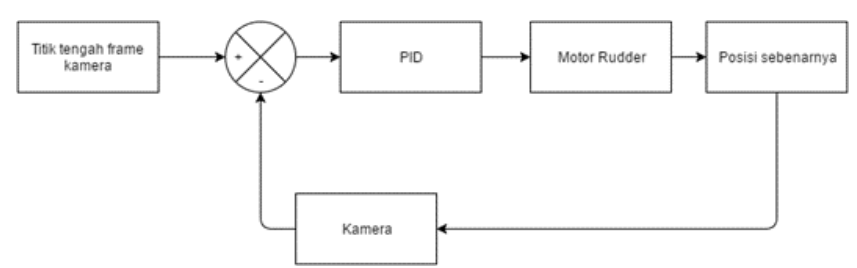

Gambar 9. Blok diagram kontrol PID arah heading balon udara

Semakin kecil nilai hasil yang didapatkan pada pengurangan nilai ini semakin besar tingkat kemiripan pada kedua gambar tersebut. Setelah titik landasan ditemukan sudut untuk pergerakan belok balon udara dapat dihitung dengan menghitung tangensial pada posisi target terhadap ujung balon udara.

\section{Perancangan kendali PID}

Pada sistem untuk mempertahankan ketinggian balon udara kendali PID menggunakan sensor ultrasonic untuk mengetahui ketinggian sebenarnya balon udara, error dari kendali PID ketinggian didapatkan dari selisih antara set point ketinggian yang diinginkan dengan ketinggian yang didapatkan dari sensor. Mikrokontroller akan mengatur kecepatan propeler pada balon udara yang sesuai untuk mempertahankan ketinggian berdasarkan error yang didapat. Blok diagram kontrol PID ketinggian dapat dilihat pada Gambar 8.

Untuk mengatur pergerakan propeler pada balon udara yang digunakan, penggerak kanan dan kiri pada sistem untuk mengatur heading balon udara diproses dengan kendali PID. Error PID adalah besar sudut antara ujung balon udara yang terdapat pada titik tengah frame dengan posisi sudut dari landasan yang sebenarnya. Blok diagram kendali PID untuk heading arah balon udara dapat dilihat pada Gambar 9.

\section{HASIL DAN ANALISA}

\section{A. Pengujian Sensor Ultrasonic}

Pengujian sensor ultrasonic ini dilakukan dengan membandingkan nilai dari sensor ultrasonic dan nilai dari alat pengukur berupa penggaris. Sensor ultrasonic ini diuji dari nilai $1 \mathrm{~cm}$ secara bertahap hingga mencapai $300 \mathrm{~cm}$, dari hasil akan dihitung nilai error-nya. Sensor ini bekerja dengan dasar selisih waktu antara sinyal yang dipancarkan dan diterima oleh transduser pada sensor ultrasonic berupa piezoelektrik. Waktu

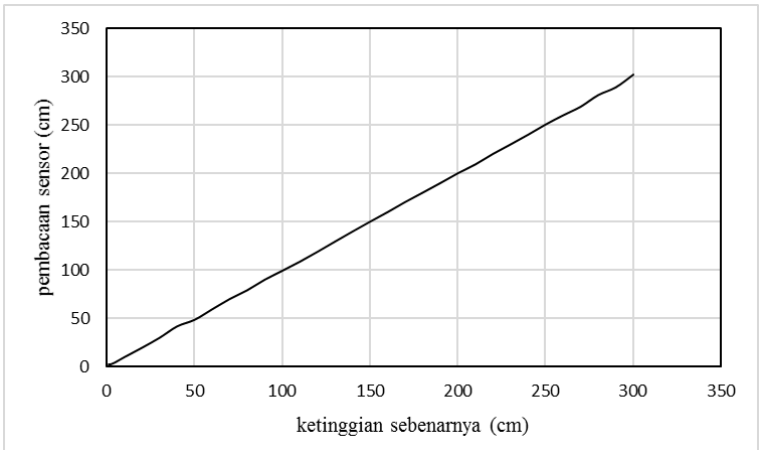

Gambar 10. Hasil pengujian sensor ultrasonic

tempuh antara sinyal yang dipancarkan dan diterima akan dihitung menggunakan mikrokontroler. Berdasarkan data yang didapat, dapat ditarik kesimpulan bahwa sensor digunakan bekerja dengan baik dan mampu untuk mengukur jarak ketinggian hingga $300 \mathrm{~cm}$.

\section{B. Pengujian Pendeteksi Landasan}

Pengujian ini dilakukan untuk membuktikan ketepatan metode $\mathrm{Hu}$ moments untuk contour matching dalam mendeteksi perubahan target landasan yang berubah secara skala, rotasi, dan translasi. Pengujian pertama ini dilakukan tanpa gangguan objek dengan warna yang sama dengan landasan dan jarak dari kamera menuju landasan diubah untuk menguji tingkat keberhasilan metode contour matching dalam mendeteksi perubahan terhadap besarnya citra landasan yang tertangkap pada kamera. Semua tingkat keberhasilan pendeteksian pada pengujian ini dihitung berdasarkan banyaknya frame yang terdeteksi pada setiap 20 frame gambar kamera yang diambil. Tingkat keberhasilan deteksi berdasarkan jarak dapat dilihat pada Tabel 2 .

Setelah diuji keakurasian dari pendeteksian landing pad berdasarkan jarak, pengujian selanjutnya akan dilakukan berdasarkan sudut pandang dari kamera. Pengujian ini dilakukan untuk menguji tingkat keberhasilan pendeteksian metode Hu moments contour matching yang citra gambar landasannya berubah secara sudut pandang kamera. pengujian dilakukan dengan merubah sudut kamera sebesar $15^{\circ}, 30^{\circ}$, dan $45^{\circ}$ terhadap landasan. Hasil pengujian tingkat keberhasilan pendeteksian landasan berdasarkan sudut kamera dapat dilihat pada Tabel 3.

Tabel 2.

Tingkat keberhasilan deteksi berdasarkan jarak

\begin{tabular}{ccc}
\hline \hline No. & Jarak $(\mathrm{cm})$ & Tingkat keberhasilan \\
\hline 1 & 20 & $100 \%$ \\
2 & 40 & $100 \%$ \\
3 & 60 & $100 \%$ \\
4 & 80 & $95 \%$ \\
5 & 100 & $100 \%$ \\
6 & 120 & $95 \%$ \\
7 & 140 & $85 \%$ \\
8 & 160 & $90 \%$ \\
9 & 180 & $90 \%$ \\
10 & 200 & $85 \%$ \\
\hline \hline
\end{tabular}

Tabel 3.

Tingkat keberhasilan berdasarkan sudut kamera

\begin{tabular}{ccc}
\hline \hline No. & Sudut $\left({ }^{\circ}\right)$ & Tingkat keberhasilan \\
\hline 1 & 15 & $55 \%$ \\
2 & 30 & $20 \%$ \\
3 & 45 & $0 \%$ \\
\hline \hline
\end{tabular}


Tabel 4.

Tingkat keberhasilan deteksi berdasarkan rotasi

\begin{tabular}{ccc}
\hline \hline No. & Rotasi $\left({ }^{\circ}\right)$ & Tingkat keberhasilan \\
\hline 1 & 0 & $95 \%$ \\
2 & 60 & $90 \%$ \\
3 & 120 & $100 \%$ \\
4 & 180 & $100 \%$ \\
5 & 240 & $90 \%$ \\
6 & 300 & $90 \%$ \\
\hline \hline
\end{tabular}

Tabel 5 .

Respon PWM dengan set point $200 \mathrm{~cm}$

\begin{tabular}{ccc}
\hline \hline No. & Jarak $(\mathrm{cm})$ & Duty Cycle $(\%)$ \\
\hline 1 & 20 & 70.57 \\
2 & 40 & 62.74 \\
3 & 60 & 54.90 \\
4 & 80 & 47.08 \\
5 & 100 & 39.21 \\
6 & 120 & 33.33 \\
7 & 140 & 22.55 \\
8 & 160 & 15.69 \\
9 & 180 & 9.82 \\
10 & 200 & 0 \\
\hline \hline
\end{tabular}

Data selanjutnya yang akan diambil adalah bagaimana tingkat pendeteksian dari sistem apabila landing pad berotasi. Pengujian ini dilakukan untuk menguji tingkat keberhasilan pendeteksian metode $\mathrm{Hu}$ moments contour matching yang citra gambar landasannya berubah secara rotasi sebesar $0^{\circ}$, $60^{\circ}, 120^{\circ}, 180^{\circ}, 240^{\circ}$, dan $300^{\circ}$. Pengujian dilakukan dengan jarak $100 \mathrm{~cm}$. Hasil pengujian dapat dilihat pada Tabel 4.

Dari serangkaian pengujian deteksi landing pad dengan metode contour matching dengan $\mathrm{Hu}$ Moments didapatkan landasan dapat terdeteksi secara rotasi dan skala namun apabila terjadi perubahan sudut pandang kamera, metode ini tidak begitu efektif.

\section{Pengujian Kontrol Kecepatan Motor Terhadap Error}

Pada pengujian ini akan diambil data uji respon pertama dari sinyal kontrol berupa duty cycle sinyal PWM terhadap ketinggian. Pengambilan data uji ini berguna untuk mengetahui seberapa besar duty cycle pertama dihasilkan PWM sehingga motor yang digunakan untuk mengangkat balon udara diharapkan dapat bekerja dengan baik. Pengujian ini lakukan dengan konstanta $\mathrm{Kp}=1, \mathrm{Ki}=0$, dan $\mathrm{Kd}=0$ dengan set point ketinggian $200 \mathrm{~cm}$. Pengujian data dilakukan dengan arduino mega, yang mempunyai sinyal PWM beresolusi 8 bit.

Dari hasil data pertama yang didapatkan dapat ditarik kesimpulan bahwa kontrol PID dapat bekerja dengan baik, dimana semakin jauh jarak antara balon dan set point yang telah ditentukan semakin besar pula duty cycle yang dihasilkan. Dengan duty cycle yang tinggi kecepatan motor juga akan berputar dengan kecepatan yang tinggi. Hasil pengujian besar PWM dapat dilihat pada Tabel 5.
D. Pengujian Kendali PID pada arah gerak balon udara

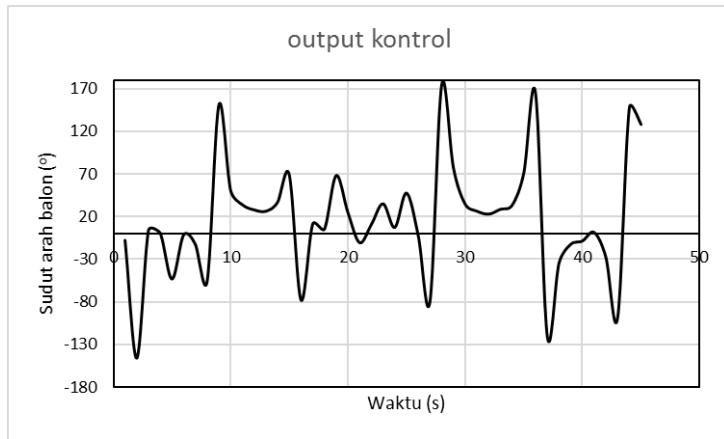

Gambar 10. Output pada kontroler tipe $\mathrm{P}$

Pengujian terakhir yang akan dilakukan adalah dengan menguji kendali PID pada sudut arah gerak maju balon terhadap target, pengujian ini bertujuan untuk mengatur pergerakan balon udara dalam menuju titik landasan dengan tepat.

Pengujian pertama dengan kendali tipe $\mathrm{P}$ dilakukan dengan mengatur $\mathrm{Kp}=1, \mathrm{Ki}=0$, dan $\mathrm{Kd}=0$. Pengujian ini bertujuan untuk melihat output kontrol berupa sudut arah gerak balon udara. Berikut adalah respon kontrol hasil dari pengujian gerak arah balon dengan set point depan balon udara yang terletak pada $0^{\circ}$ pada sudut frame kamera.

Dari data yang diperoleh dapat dilihat bahwa respon kontrol dari kendali PID pada arah gerak balon udara sudah mempunyai kemampuan untuk mengoreksi error untuk menuju pada titik set point $0^{\circ}$ dalam arah gerak balon, namun dikarenakan respon dari kontroler $\mathrm{P}$ yang kurang cepat sehingga offset dan error yang terjadi masih relatif besar.

Maka dari itu dengan metode tuning PID ziegler-nichols yang pertama akan ditentukan konstanta kp, ki, dan kd untuk mendapatkan respon yang plant yang lebih baik. Dengan memberi unit step pada balon udara kita dapat menentukan konstanta yang tepat respon kontrol yang terjadi pada balon udara. Berikut adalah perhitungan output dari plant yang telah diberikan, konstanta kp, ki, dan kd dapat ditentukan dengan tabel formula ziegler-nichols. Dari gambar respon output yang telah diperoleh nilai dari $\mathrm{T}$ dan $\mathrm{L}$ telah diketahui.

$$
\begin{gathered}
\mathrm{T}=1 \mathrm{~s} \\
\mathrm{~L}=0.3 \mathrm{~s} \\
\mathrm{Kp}=1.2 \frac{\mathrm{T}}{L}=4 \\
\mathrm{Ki}=0.6 \frac{\mathrm{T}}{\mathrm{L}^{2}}=6.67 \\
\mathrm{Kd}=0.6 \mathrm{~T}=0.6
\end{gathered}
$$

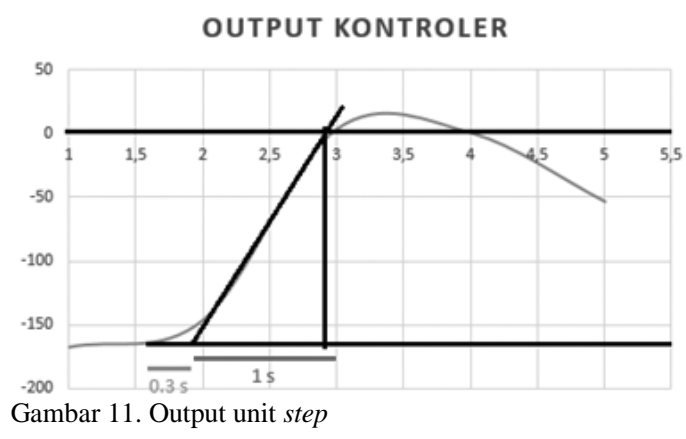




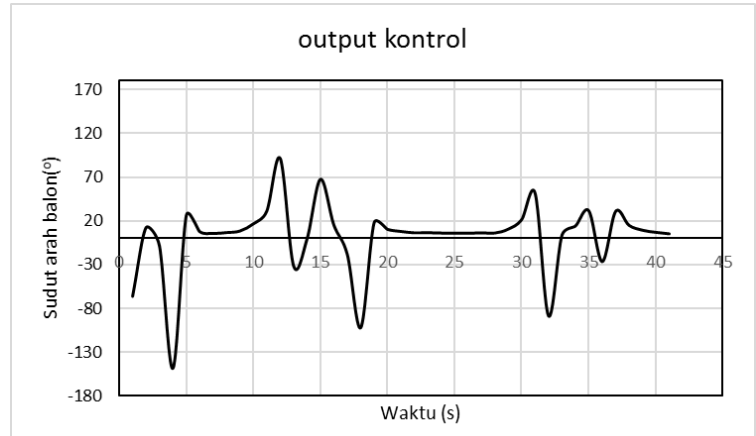

Gambar 12. Output pada kontroler PID

Setelah mengetahui konstanta $\mathrm{Kp}, \mathrm{Ki}$, dan $\mathrm{Kd}$ arah gerak balon udara akan diuji kembali, berikut adalah hasil pengujian dari kontrol balon udara setelah $\mathrm{Kp}, \mathrm{Ki}$, dan $\mathrm{Kd}$ telah diatur menggunakan metode tuning ziegler nichols.

Terlihat dari respon kontrol dengan konstanta $\mathrm{Kp}, \mathrm{Ki}$, dan Kd yang telah diatur menggunakan metode ziegler nichols mempunyai respon yang lebih cepat dalam mengkoreksi kesalahan sudut arah gerak balon lebih cepat dari respon yang hanya menggunakan kontroler tipe P. Error osilasi pada gerak arah balon yang terjadi juga berkurang.

\section{KESIMPULAN}

Dari serangkaian percobaan yang telah dilakukan dapat ditarik kesimpulan bahwa penggunaan metode contour matching dengan $\mathrm{Hu}$ moments mempunyai ketelitian yang tinggi untuk perubahan skala, rotasi, dan translasi. Pada translasi keakurasian pendeteksian mencapai $94 \%$ dengan perubahan besar landasan pacu terhadap ketinggian dan pada rotasi metode ini juga mencapai $94 \%$, namun jika terjadi perubahan sudut pandang kamera keakurasian pendeteksian landasan berada dibawah 55\%. Sehingga metode ini tidak cocok apabila sudut pandang kamera berubah terlalu besar. Serta penggunaan kontrol PID lebih efektif daripada menggunakan hanya kontroler tipe $\mathrm{P}$, kontroller PID pada balon udara yang digunakan mampu mengurangi sudut osilasi pada kontrol arah balon sebesar $50^{\circ}$ dan mampu mempertahankan nilai set point lebih lama dibandingkan kontroller tipe $\mathrm{P}$.

\section{DAFTAR PUSTAKA}

[1] Tan Kok Ping, Julian; Eng Ling, Ang; Jun Quan, Tan; Yea Dat, Chua. (2012). "Generic Unmanned Aerial Vehicle (UAV) for civilian application". Faculty of Engineering and Science, Universiti Tuanku Abdul Rahman (UTAR), Kuala Lumpur, Malaysia.

[2] Vincenzo Angelino, Cesario; Rosario Baraniello, Vincenzo; Cicala; Choi, Sujin; Lee, Boram; Kim, Bosung; Park, Noha; Kim, Dongkeon; Luca. (2013). "High Altitude UAV Navigation using IMU, GPS and Camera". CIRA, the Italian Aerospace Research Centre.

[3] Maâlej, Imen; Ouali, Mohamed; Derbel, Nabil. (2012)."MODULAR ULTRASONIC SENSOR PLATFORM FOR MOBILE ROBOT". University of Sfax, ENIS, Research Unit on Intelligent Control, design \& Optimisation of complex Systems (ICOS).

[4] Jerónimo, David; Alcácer, Ricardo; Alegria, F. C.; Lima, Pedro U. (2015). "Line Following and Ground Vehicle Tracking by an Autonomous Aerial Blimp". Institute for Systems and Robotics Lisboa.

[5] Liu, Yun; Yin, Yanmin; Zhang, Shujun. (2012). "Hand Gesture Recognition Based on HU Moments in Interaction of Virtual Reality". College of Information Science and Technology Qingdao University of Science and Technology.
[6] Lin, Feng; Duan, Haidong; Qu, Xiaoguang. (2014). "PID Control Strategy for UAV Flight Control System based on Improved Genetic Algorithm Optimization". Automation Department, Shenyang Aerospace University, Shenyang 110136, China. 